\title{
A ZÖLDENERGIÁK ELŐÁLLÍTÁSÁNAK TECHNIKAI ASPEKTUSAI
}

\section{SOME TECHNICAL ASPECTS REGARDING THE GREEN ENERGIE PRODUCING}

\author{
Gyenge Csaba \\ Kolozsvári Müszaki Egyetem, Gépgyártás-technológiai Tanszék, 400641 Cluj- \\ Napoca, B-dul Muncii nr.103-105, tel/fax: +40-264-415001, Csa- \\ ba.Gyenge@tcm.utcluj.ro.
}

\begin{abstract}
In the first part of paper, I present the constructive particularities of special gear boxes used at vertical tower wind turbines and the quality requirements. In the following part I present the new CNC gear grinding methodology and technology, developed by our team, with which it was possible to realize the high quality of geometrical parameters and quality roughness. In the last part of paper I will present some the practical industrial results and used control technology.
\end{abstract}

Keywords: green energy, wind turbines, gearing.

\section{Összefoglalás}

A dolgozat első részében ismertetem a függőleges tornyú szélturbinák szerkezetében alkalmazott fogaskerék hajtóművek konstruktív jellegzetességeit és a minőségi igényeket. A második részben röviden bemutatom az általunk kifejlesztett CNC köszörülési technológiát, amellyel el lehet érni a különleges fogazatok pontossági és felületminőségi követelményeit. A dolgozat végén ismertetem az ipari megvalósításainkat és a jellegzetes mérési eredményeket.

Kulcsszavak: zöldenergia, szélturbina, hajtómü

\section{Bevezető}

Ismeretes, hogy a megújulóenergiaforrások szerepe folytonosan nö, és a Greenpeace becslései szerint 2050-ben Románia az összenergia-szükségletének 85\%-át megújuló forrásokból kell fedezze. A Román Statisztikai Intézet adatai szerint [7], 2011-ben az össz 63252 GkW kitermelt energiából 40\%-ot a gázalapú hőerőmüvek termelték, 22\%-ot a vízerömüvek, 16\%-ot az atomerömü és csak 4\%-ot a szélerőmüvek. Az optimista előrejelzések szerint, 2013 végéig a szélerőmüvekben termelt energia meg kell duplázodjon, és igy Románia világviszonylatban a 13-ik helyet foglalhatja majd el a szélenergia felhasználása terén (a legújabb értesülések szerint már $7 \%$ felett van).

Természetes, hogy a szélerőmüvek felépítése elég komplex, és az előállítási, valamint felszerelési áruk elég magas, így egyelőre - a szélerőmüvekben előállított energia ára jóval magasabb, mint a hő-, vagy vízerőmüvekben előállítotté. Viszont a gáz-, valamint szénhidrátkészletek elég gyors csökkenése arra figyelmeztet, hogy minél íntenzivebben foglalkozzunk az újrahasznosítható üzemeanyaggal múködő energiatermelökkel. 
Kutatócsoportunk több mint 4 éve foglalkozik a szélturbinákban alkalmazott hajtómüvek gyártástechnológiájának fejlesztésével annak érdekében, hogy minél kisebb költségekkel minél jobb minőséget és élettertamot lehessen elérni a szükséges fogaskerék-hajtómüvek számára.

A dolgozat keretében igyekszem ismertetni ez irányú jellegzetes elméleti és gyakorlati kutatásaink eredményeit.

\section{A szélturbinákban alkalmazott hajtómúvek konstruktív és müködési jellegzetességei}

Ismereteink szerint [8] a napjainkban alakalmazott szélerőmüvek nagy része vízszintes tengelyü lapáttal dolgozik

(1. ábra).

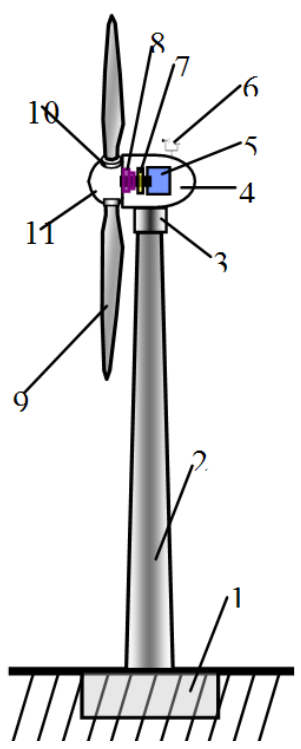

1.ábra. Vizszintes

tengelyü

szélturbina felépítése: 1 - fundamentum, 2 - torony, 3 - szélirányra állitó berendezés, 4 gondola, 5 -generátor, 6 -szélmérö, 7 fék, 8 - hajtómü, 9 - rotorlapát, 10 lapát irányitó, 11 -forgószárnyagy.

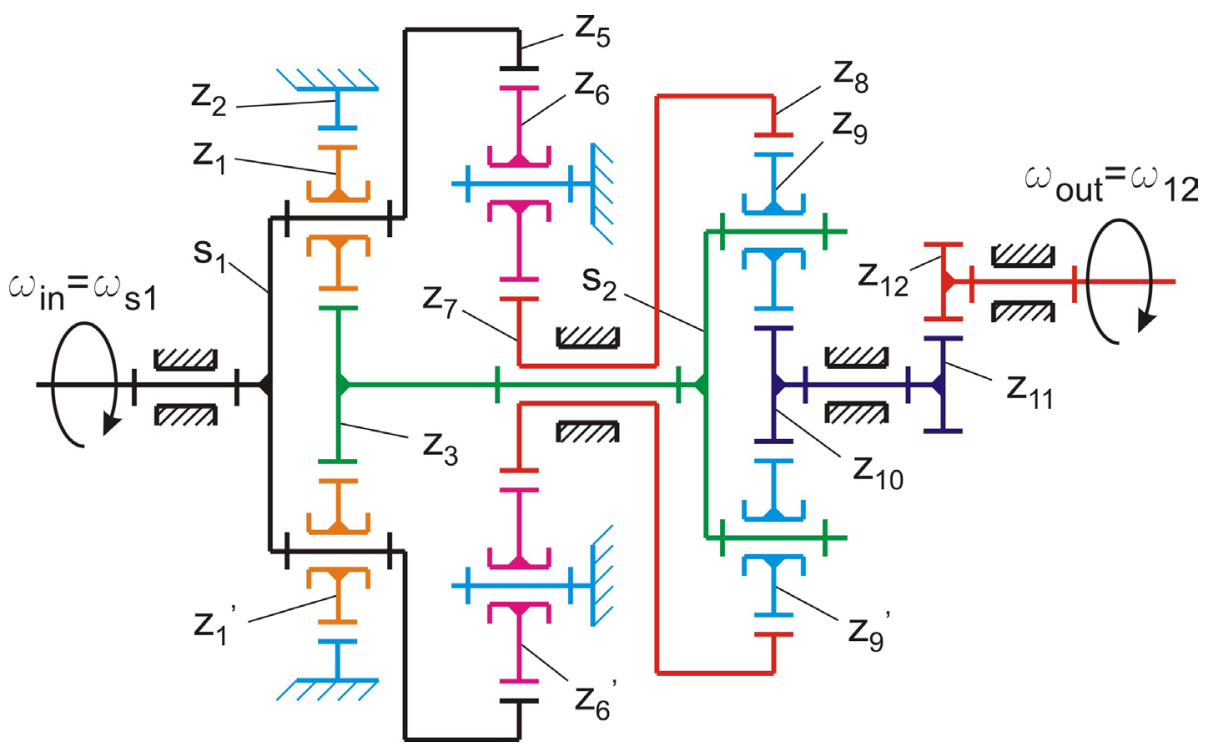

2. ábra. A kétlépcsős bolygó rendszerü multiplikátor kinematikai vázlata 
Amint az ábrán láthatjuk, a primer tengely (amin a paletták vannak) kis fordulatszámú forgása bemegy a multiplikátorba, ahonnan egy tengelykapcsoló révén (amelyik szükség esetén fékként is müködik) meghajtja az áramgenerátor tengelyét.

Rendszerint a fordulatszám-növelö (multiplikátor) bolygó felépítésü (2. ábra), és aránylag kis méretek mellett nagy áttételi arányokat kell biztosítson.

Amint az ábrán láthatjuk, a légcsavarok primer tengelye végén az $S_{l}$ kapcsoló fedél van rögzítve, amelyben a három $Z_{1}$ bolygókerék van beágyazva. A fedél jóbb oldalán a $Z_{5}$ belső fogazatú kerék van felfogva. Az említett bolygókerekek úgy a $Z_{2}$ belső fogazatú keréken gördülnek, mint a $Z_{3}$ keréken. Ezzel egyidőben, a belső fogazatú $Z_{5}$ kerék forgatja a $Z_{6}$ bolygókerekeket. és ezek meghajtják a $Z_{7}$ kereket, amelyik össze van kötve a $Z_{8}$ koszorúkerékkel, amelynek fogfelületein gördülnek a $Z_{9}$ bolygókerekek. Ezek a bolygókerekek hajtják meg a $Z_{10}$ fogaskereket. Ennek tengelyén fekszik a $Z_{11}$ kerék, amely a $Z_{12}$ kerék révén meghajtja a kimenő tengelyt. A fentiek szerint a hajtómü nagy átviteli arányt tud biztosítani ( például 50:1-hez).
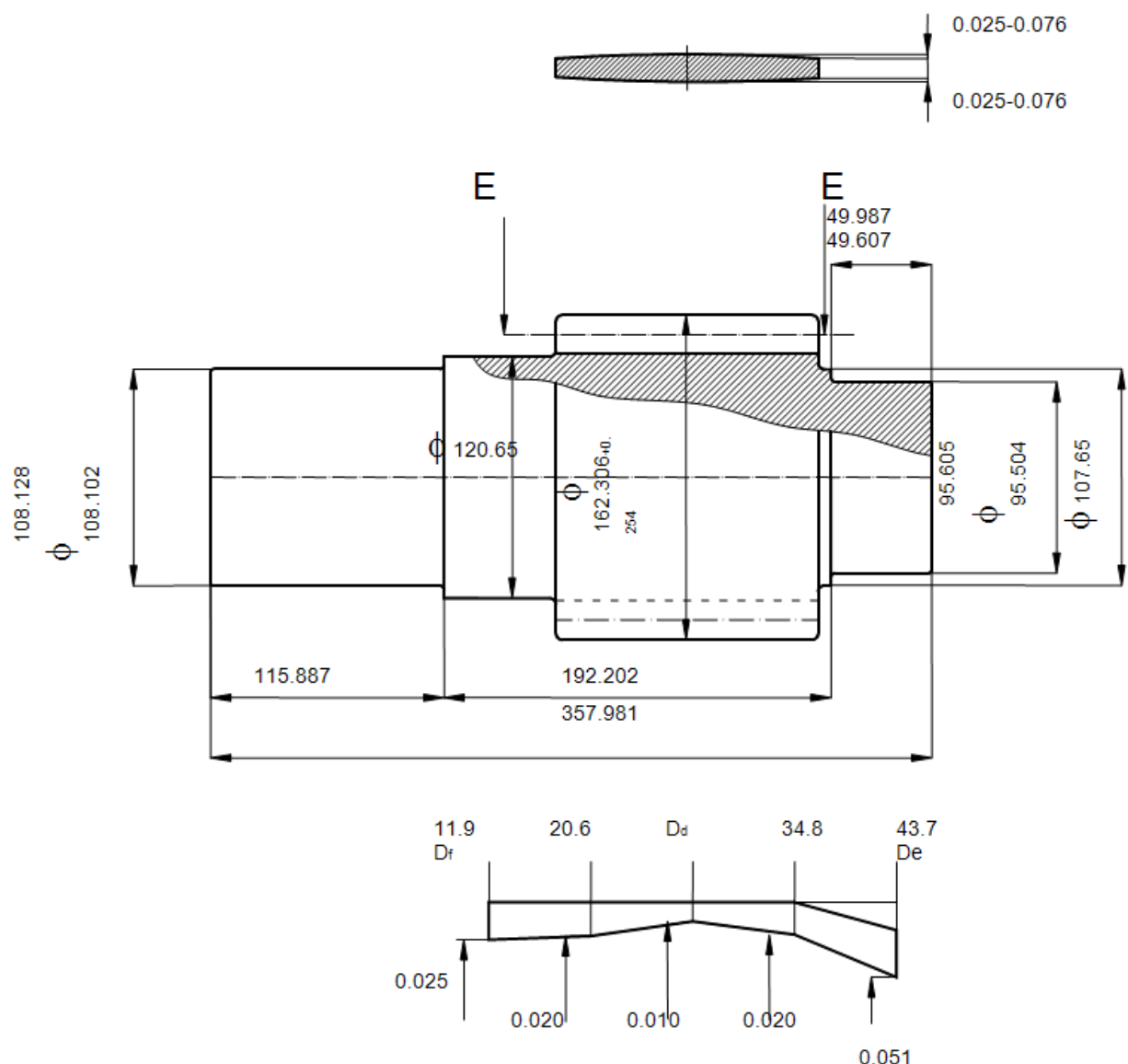

3. ábra. A gyakorlati kísérletek keretében gyártott bolygókerék rajza 
Mivel ezek a hajtómüvek nagy magasságban kell müködjenek és turbinák sokszor igen változatos terepre vannak beépitve, mind szerelésük, mind karbantartásuk elég nehéz. Ezért a technikai feltételek minimum 10 éves élettertamot igényelnek.

Ugyanakkor a nagy magasságban való müködésük minél kisebb rezgésekkel kell járjon, ellenkező esetben károsan befolyásolják a terep állatvilágát.

$\mathrm{Az}$ említett igényeket csak igen komplex és nagy pontosságú fogaskerékhajtómüvekkel lehet kielégíteni.

Kutatásaink keretében az $m=8 . .14$ $m m$-rü bolygókerekek technológiájával foglalkoztunk. A 3. ábrán a kerék konstrukciós rajza látható, valamint az $\mathbf{1}$ táblázatban a technikai adatai.

Amint a 3. ábra alsó részén láthatjuk, a fogprofil eltér a hagyományos evolvens fogazatok alakjától, és annak érdekében, hogy ezt a komplex alakú fogazatot megfelelő pontossággal és felületi érdességgel lehessen megmunkálni, a CNC vezérléshez folyamodtunk.

1. táblázat A 3. ábrán feltüntetett bolygókerék adatai

\begin{tabular}{|l|l|l|l|}
\hline Fogszám & 17 & Pitch diameter & 142.24 \\
\hline $\begin{array}{c}\text { Diametral } \\
\text { pitch }\end{array}$ & 3.0357 & $\begin{array}{l}\text { Alapkör- } \\
\text { átmérő }\end{array}$ & 128.913 \\
\hline Modul & 8.367 & $\begin{array}{l}\text { Fejkör } \\
\text { átméröje }\end{array}$ & 162.306 \\
\hline $\begin{array}{c}\text { Kapcsoló } \\
\text { szög }\end{array}$ & $25^{\circ}$ & Fogmagasság & 10.033 \\
\hline
\end{tabular}

\section{A kifejlesztett fogazat simítási technológia}

A szélturbinák hajtómüveiben alkalmazott komplex profilkorrekciós fogaskerekek simító megmunkálása érdekében a nagyváradi TECHTRANS, valamint a szatmárnémeti UNIO gyárakkal közösen, egy hagyományos NILES tipusú fogaskerék-köszörügépet felújítottunk, japán FANUC vezérléssel (4. ábra).

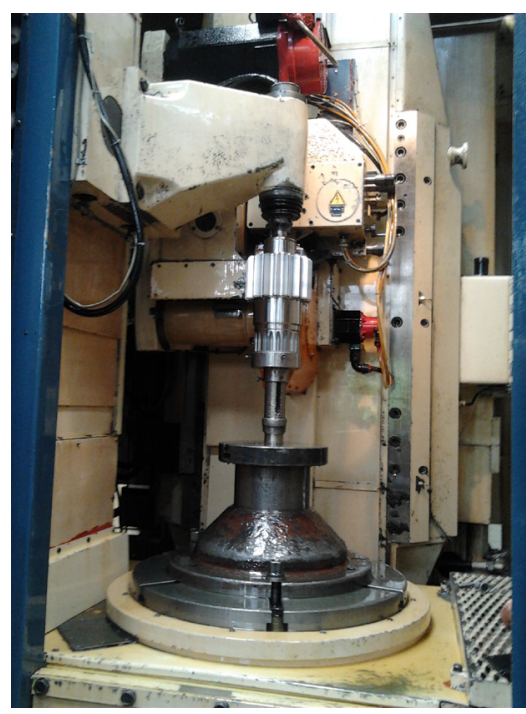

4. ábra. A FANUC vezérléssel felújitott fogköszörügép munkatere

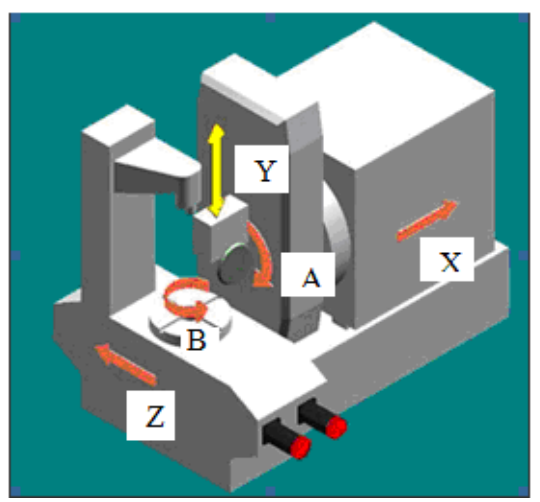

5. ábra. A CNC fogköszörügép felépitése és koordináta-rendszere

A köszörülendö fogaskerék legördülési mozgását a köszörükorong által megvalósított burkoló fogaslécen, a Z tengelyirányú elmozdulás, valamint a B tengely körüli forgással valósítottuk meg (5. ábra). $\mathrm{Az} \quad \mathrm{X}$ tengelyirányú mozgás szintén CNC vezérelt, és vele bizosítható a szükséges tengelytávolság. $\mathrm{Az} \quad \mathrm{Y}$ tengelyirányú mozgással a hosszirányú profilmódosításokat lehet programozni, míg 
az X tengely körüli forgással a szerszám dőlési szögét.

Általában egy profilkorrekció nélküli fogárok megköszörüléséhez a 2. táblázatban feltüntetett müveletelemek szükségesek.

2. táblázat. Egy fogárok köszörüléséhez szükséges alapmüvelet-elemek

\begin{tabular}{|c|c|}
\hline $\begin{array}{c}\mathrm{A} \\
\text { müveletelem } \\
\text { száma }\end{array}$ & Múveletelem elnevezése \\
\hline fo & $\begin{array}{l}\text { A szerszám megfelelö beállítása } \\
\text { az előmunkált fogárokba }\end{array}$ \\
\hline fl & $\begin{array}{l}\text { Beforgatás a bal fogoldal } \\
\text { kezdőpontjába }\end{array}$ \\
\hline $\mathrm{f} 2$ & $\begin{array}{l}\text { A szerszám és az előnagyolt bal } \\
\text { fogoldal közötti játék } \\
\text { megszüntetése }\end{array}$ \\
\hline f3 & A bal fogoldal köszörülése \\
\hline $\mathrm{f} 4$ & Átgördítés a jobb fogoldalra \\
\hline f5 & $\begin{array}{l}\text { A szerszám és az elönagyolt } \\
\text { jobb fogoldal közötti játék } \\
\text { megszüntetése }\end{array}$ \\
\hline f6 & A jobb fogoldal köszörülése \\
\hline f7 & Egy foggal való osztás \\
\hline
\end{tabular}

A profilkorrekciós fogprofilok legördüléséhez az f3 és f4 müveletelemeket fel kellet bontani három illetve négy szakaszra.

Ezek szerint egy profilkorrekciós fogárok köszörüléséhez minimum 14 müveletelem paramétereit kellett meghatározni. Erre a célra több matematikai algoritmust fejlesztettünk ki.

\section{A CNC vezérlés programo- zásához szükséges paraméterek meghatározásához kifejlesztett algoritmusok}

A CNC vezérlést igen precizen kellett beprogramozni, valamennyi müveletelem számára, föleg a profilkorrekciós fogazatok esetében. Ennek érdekében egy saját elképzelés szerint a fogrofil három jellegzetes részét, három különböző evolvens szakasszal valósítottam meg (6. ábra).

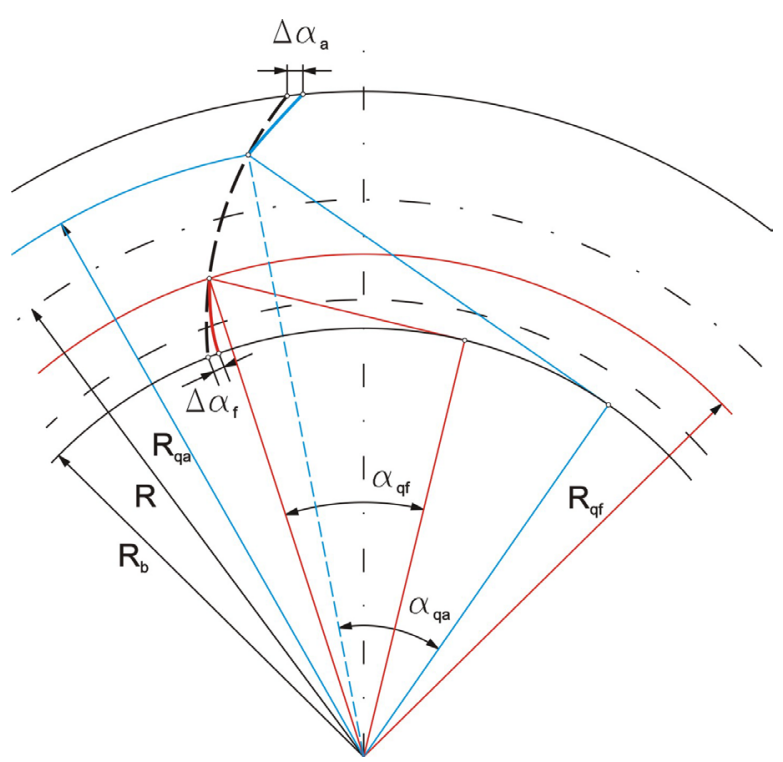

6. ábra. A három evolvens szakaszból kialakított fogprofil 
A három evolvens szakasz burkolása három kapcsoló egyenesen történik, amelyek az $R_{b f}, R_{b}$ és $R_{b a}$ alapkörökhöz tartoznak (7. ábra).

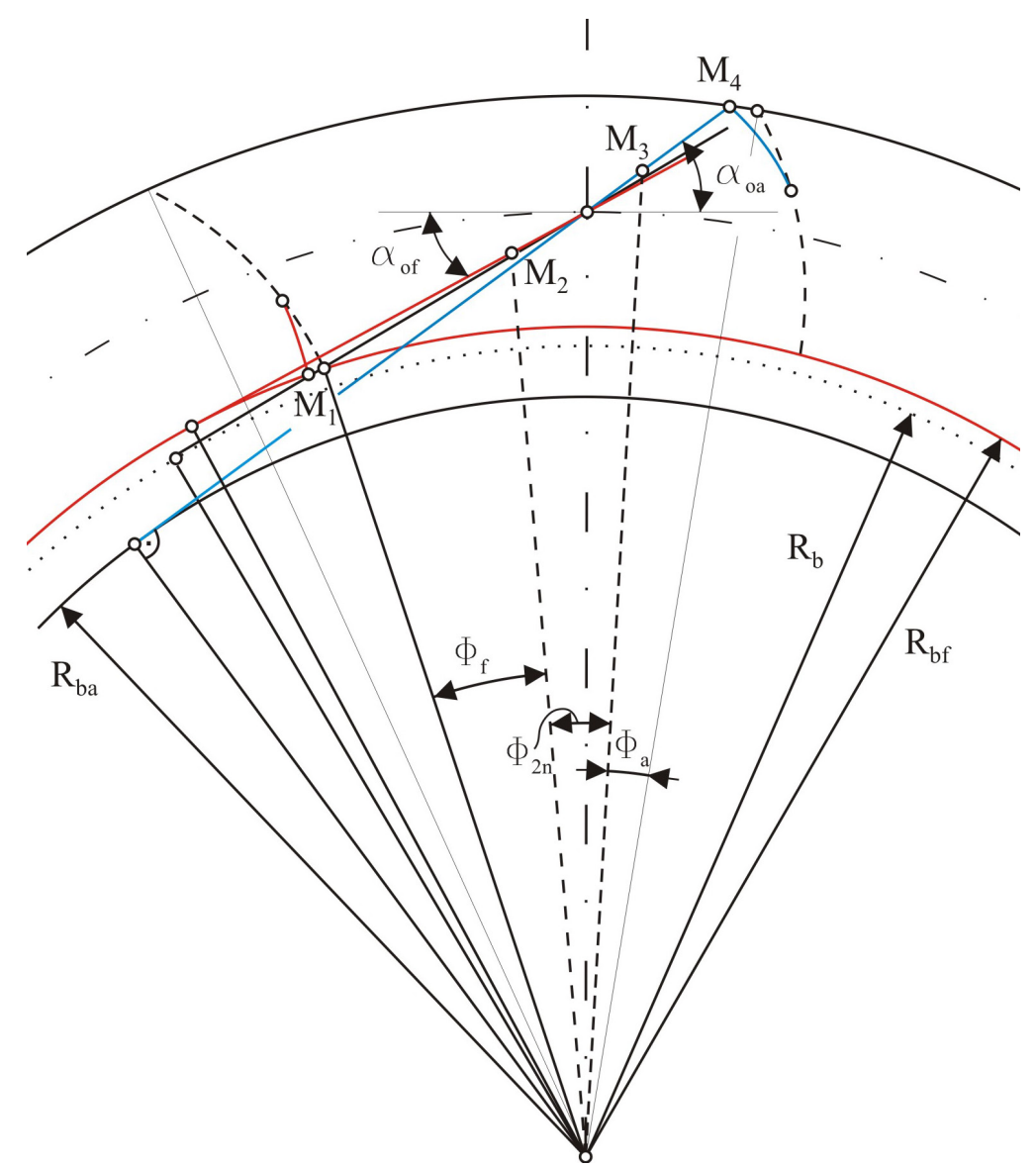

7. ábra. A profilkorrekciós fogprofil kapcsoló egyenesei

Az algoritmusok felépítése céljából pontosan meg kellett határozni a technológiai kapcsoló pár jellegzetes relatív helyzeteit (8. ábra).

Az ábrán látható tangenciális, valamint forgásirányú paraméterek meghatározása céljából több algoritmust fejlesztettünk ki a különböző szabványok szerint tervezett fogaskerekek számára (DIN, STAS, AGMA, Stb.) (3. táblázat). 


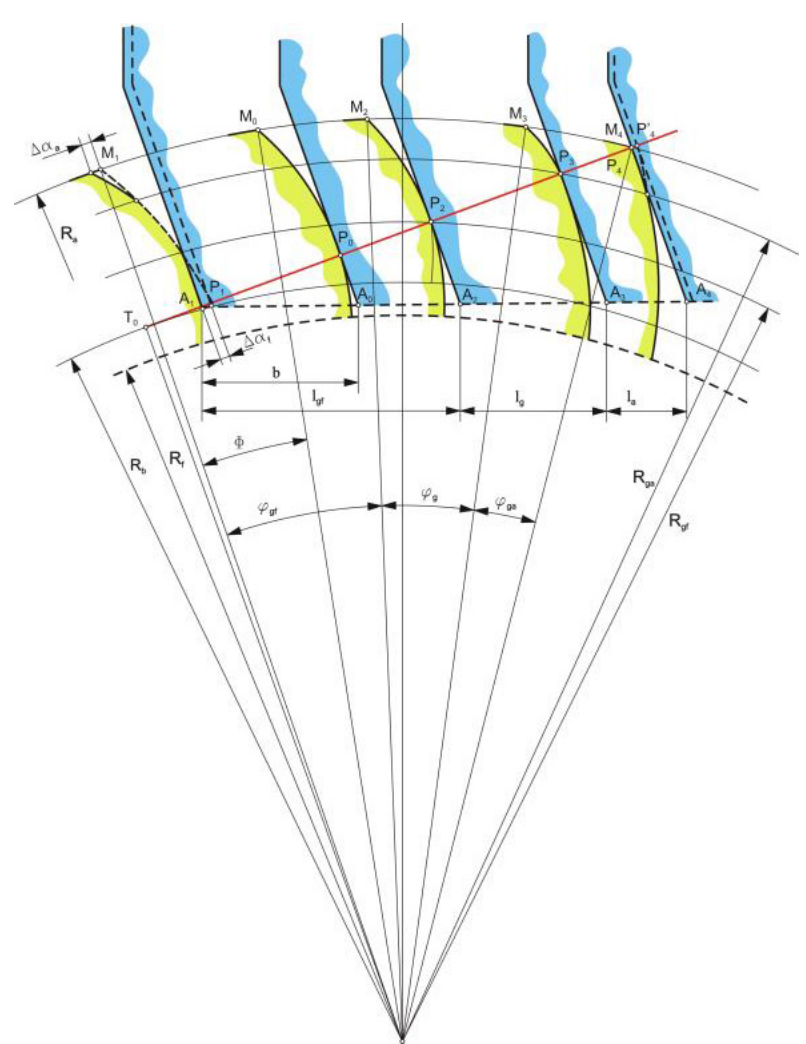

8. ábra. A technológiai kapcsoló pár jellegzetes helyzetei, CNC fogköszörülésnél

3. táblázat. Kifejlesztett algoritmusok hengeres fogaskerekek CNC köszörülésére

\begin{tabular}{|c|c|l|l|}
\hline Szám & $\begin{array}{c}\text { Algoritmus } \\
\text { kódja }\end{array}$ & \multicolumn{1}{|c|}{ Elnevezése } & Alkalmazási terület \\
\hline 1 & Ag. 1.1. & $\begin{array}{l}\text { Általános algoritmus profileltolásos } \\
\text { dőlt fogú fogaskerekek számára }\end{array}$ & $\begin{array}{l}R_{f} \leq R_{b} \cos \alpha_{t} \\
\alpha_{t} \neq \alpha_{s}\end{array}$ \\
\hline 2 & Ag. 1.m & $\begin{array}{l}\text { Módosított algoritmus profileltolá- } \\
\text { sos és profilkorrekciós dőlt fogú fo- } \\
\text { gaskerekek számára }\end{array}$ & $\begin{array}{l}R_{f} \leq R_{b} \cos \alpha_{t} \\
\alpha_{t} \neq \alpha_{s}\end{array}$ \\
\hline 3 & Ag. 1m.x & $\begin{array}{l}\text { Módosított algoritmus profileltolá- } \\
\text { sos és profilkorrekciós AGMA fo- } \\
\text { gaskerekek számára }\end{array}$ & $\begin{array}{l}R_{f} \leq R_{b} \cos \alpha_{t} \\
\alpha_{t} \neq \alpha_{s}\end{array}$ \\
\hline 4 & Bg. 1.1 & $\begin{array}{l}\text { Általános algoritmus profilkorrekció } \\
\text { nélküli egyenes fogú fogaskerekek } \\
\text { számára }\end{array}$ & $\begin{array}{l}R_{f} \geq R_{b} \cos \alpha_{t} \\
\alpha_{t} \neq \alpha_{s}\end{array}$ \\
\hline
\end{tabular}




\begin{tabular}{|c|c|l|c|}
\hline 5 & Bg. 1.m & $\begin{array}{l}\text { Módosított algoritmus profileltolá- } \\
\text { sos és profilkorrekciós egyenes fogú } \\
\text { fogaskerekek számára }\end{array}$ & $\begin{array}{l}R_{f} \geq R_{b} \cos \alpha_{t} \\
\alpha_{t} \neq \alpha_{s}\end{array}$ \\
\hline 6 & Bg.1.m.x & $\begin{array}{l}\text { Módosított algoritmus profileltolá- } \\
\text { sos és profilkorrekciós AGMA ferde } \\
\text { fogú fogaskerekek számára }\end{array}$ & $\begin{array}{l}R_{f} \geq R_{b} \cos \alpha_{t} \\
\alpha_{t} \neq \alpha_{s}\end{array}$ \\
\hline
\end{tabular}

A 4. táblázatban egyenes fogazatú, AGMA normák szerint tervezett profilkorrekciós fogaskerekek CNC köszörüléséhez

szükséges paraméterek matematikai meghatározása látható.

4. táblázat. Bg.1m. Algoritmus a módositott algoritmus profileltolásos és profilkorrekciós egyenes fogú, AGMA normák szerint tervezett fogaskerekek CNC köszörüléséhez

\begin{tabular}{|c|c|c|}
\hline $\begin{array}{c}\text { Fog- } \\
\text { szakasz }\end{array}$ & Z irányú tangenciális mozgás & B irányú körmozgás \\
\hline Láb & $l_{g f}=-\left[\frac{1}{\cos \alpha_{s}}\left(\sqrt{R_{q f}^{2}-R_{b}^{2}}+\Delta \alpha_{f}\right)\right]$ & $\varphi_{q f}=\operatorname{arctg}\left[\frac{\sqrt{R_{q f}^{2}-R_{b}^{2}}}{R_{b}}-\frac{\Delta \alpha_{f}}{R_{f}}\right]$ \\
\hline Közép & $l_{g}=-\frac{1}{\cos \alpha_{s}}\left[\sqrt{R_{q a}^{2}-R_{b}^{2}}-\sqrt{R_{q f}^{2}-R_{b}^{2}}\right]$ & $\varphi_{g}=\operatorname{arctg} \frac{\sqrt{R_{q a}^{2}-R_{b}^{2}}-\sqrt{R_{q f}^{2}-R_{b}^{2}}}{R_{b}}$ \\
\hline Fej & $l_{g a}=-\left[\frac{\sqrt{R_{a}^{2}-R_{b}^{2}}-\sqrt{R_{g}^{2}-R_{b}^{2}}}{\cos \alpha_{s}}-\Delta \alpha_{a}\right]$ & $\varphi_{g a}=\operatorname{arctg}\left[\frac{\sqrt{R_{a}^{2}-R_{b}^{2}}-\sqrt{R_{q a}^{2}-R_{b}^{2}}}{R_{b}}-\frac{\Delta \alpha_{a}}{R_{b}}\right]+\Delta \alpha_{f}$ \\
\hline
\end{tabular}

Természetesen a megvalósított CNC géppel bármilyen profileltolásos fogazat is köszörülhető.

Ugyanakkor megfelelő programozással körhagyó fogazatok (9. ábra) is köszörülhetők, anélkül hogy bármilyen sablonra vagy más vezérlésre szükség lenne.

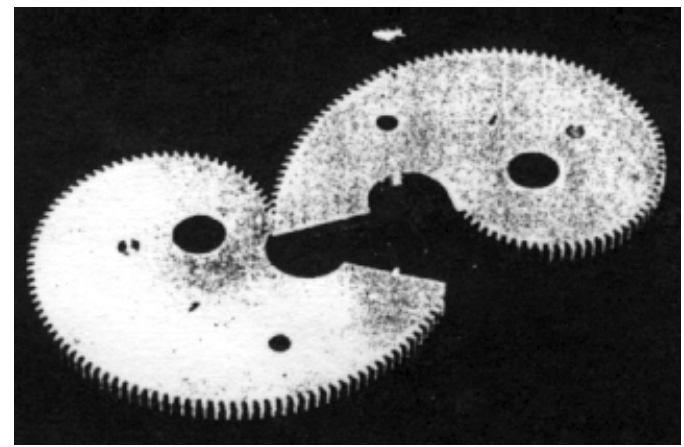

9. ábra. Körhagyó fogaskerék 
A fentiekből megállapíthatók a kifejlesztett fogköszörügép és technológia legfontosabb jellemzői:

- nincs szükség a hagyományos beállításhoz szükséges váltókerekekre, és ezáltal a beállítás nagyon egyszerü;

- a beállítás a géphez csatolt számítógéppel történik;

- a gép rugalmas, többcélú felhasználást biztosít;

- bármilyen profilkorrekció és profileltolás megvalósítható;

- nem szükséges a szerszám és a megmunkálandó fogazat profilszögeinek egyenlönek lennie;

- megfelelő továbbfejlesztéssel hordóalakú, valamint hengeres-kúpos (Maag Taschenbuch 1985) fogaskerekek is köszörülhetők.

\section{Ipari kutatások}

A kifejlesztett technológiát a szatmárnémeti UNIO gyárban vezettük be, és mai napig is sikeresen alkalmazzák.
Az előzetes gyakorlati kísérleteket az 5. táblázatban ismertetett adatú fogaskerekekre végeztük.

A teszt fogaskerekeket egy $\mathrm{CNC}$ fogaskerékmérő központon ellenőriztük (10. ábra).

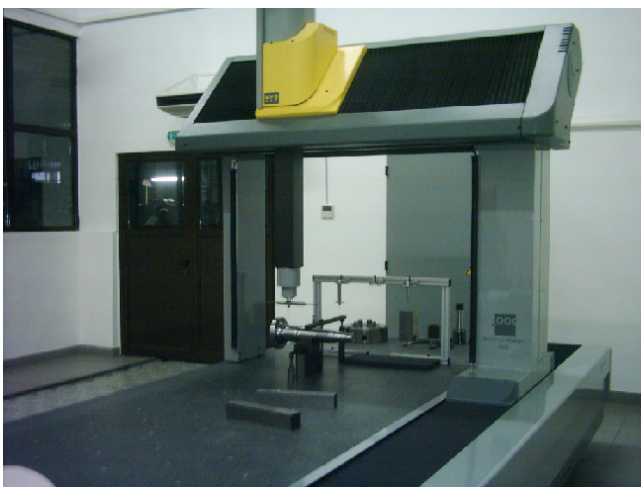

10. ábra. Az UNIO gyár tulajdonában lévö CNC fogaskerék-ellenörzö központ

A 11. és 12. ábrákon a fogprofil, valamint osztáshiba diagramjai láthatók.

5. táblázat. A gyakorlati kísérletek keretében megmunkált és leellenörzött fogaskerekek adatai

\begin{tabular}{|l|l|c|c|c|c|c|c|}
\hline \multicolumn{1}{|c|}{$\mathbf{N}^{\mathbf{0}}$} & norm & $\mathbf{m}_{\mathrm{n}}$ & $\mathbf{z}$ & $\boldsymbol{\alpha}$ & $\boldsymbol{\beta}$ & $\begin{array}{c}\text { Addendum } \\
\text { modification }\end{array}$ & $\begin{array}{c}\text { Profile } \\
\text { modification }\end{array}$ \\
\hline Wheel 1 & DIN & 12 & 18 & $20^{0}$ & 0 & 0 & - \\
\hline Wheel 2 & AGMA & 10,808511 & 30 & $28^{0}$ & 0 & 0 & $\Delta \alpha_{f}=0,027$ \\
& & & & & & & \\
\hline Wheel 3 & DIN & 8 & 70 & $20^{0}$ & $10^{0}$ (left) & $\mathrm{x}=-0,411$ & - \\
\hline Wheel 4 & DIN & 8 & 16 & $20^{\circ}$ & $\begin{array}{c}10^{0} \\
\text { (right) }\end{array}$ & $\mathrm{x}=0,411$ & - \\
\hline Wheel 5 & DIN & 12 & 14 & 20 & 0 & 0 & - \\
\hline Wheel 6 & AGMA & $\begin{array}{c}10,948275 \\
(\mathrm{DP}-2,32)\end{array}$ & 18 & $25^{\circ}$ & 0 & 0 & $\Delta \alpha_{f}=\Delta \alpha_{a}$ \\
& & & & & & 0,038 \\
\hline
\end{tabular}




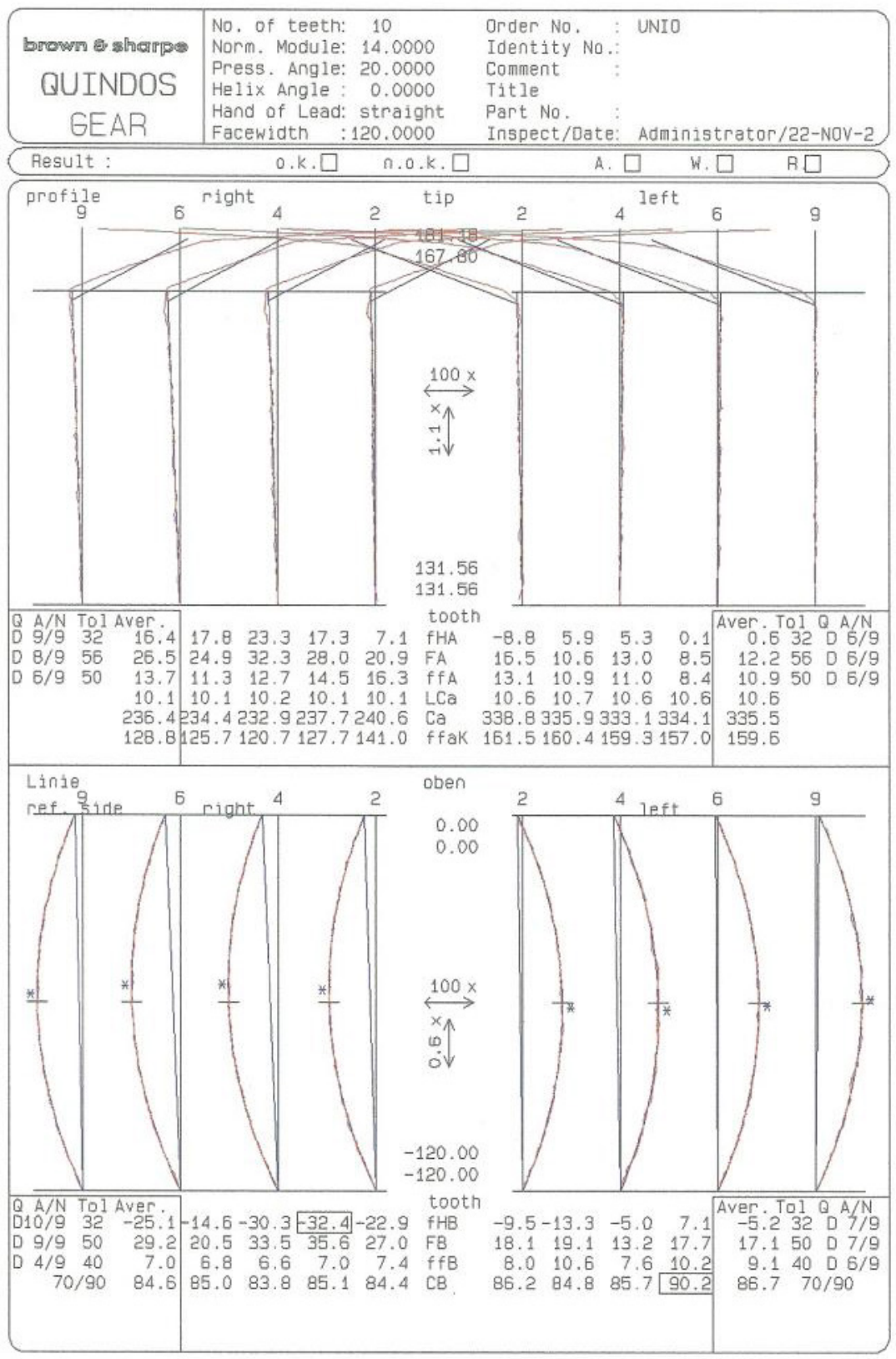

11. ábra. A fogprofil és -irány diagramja 


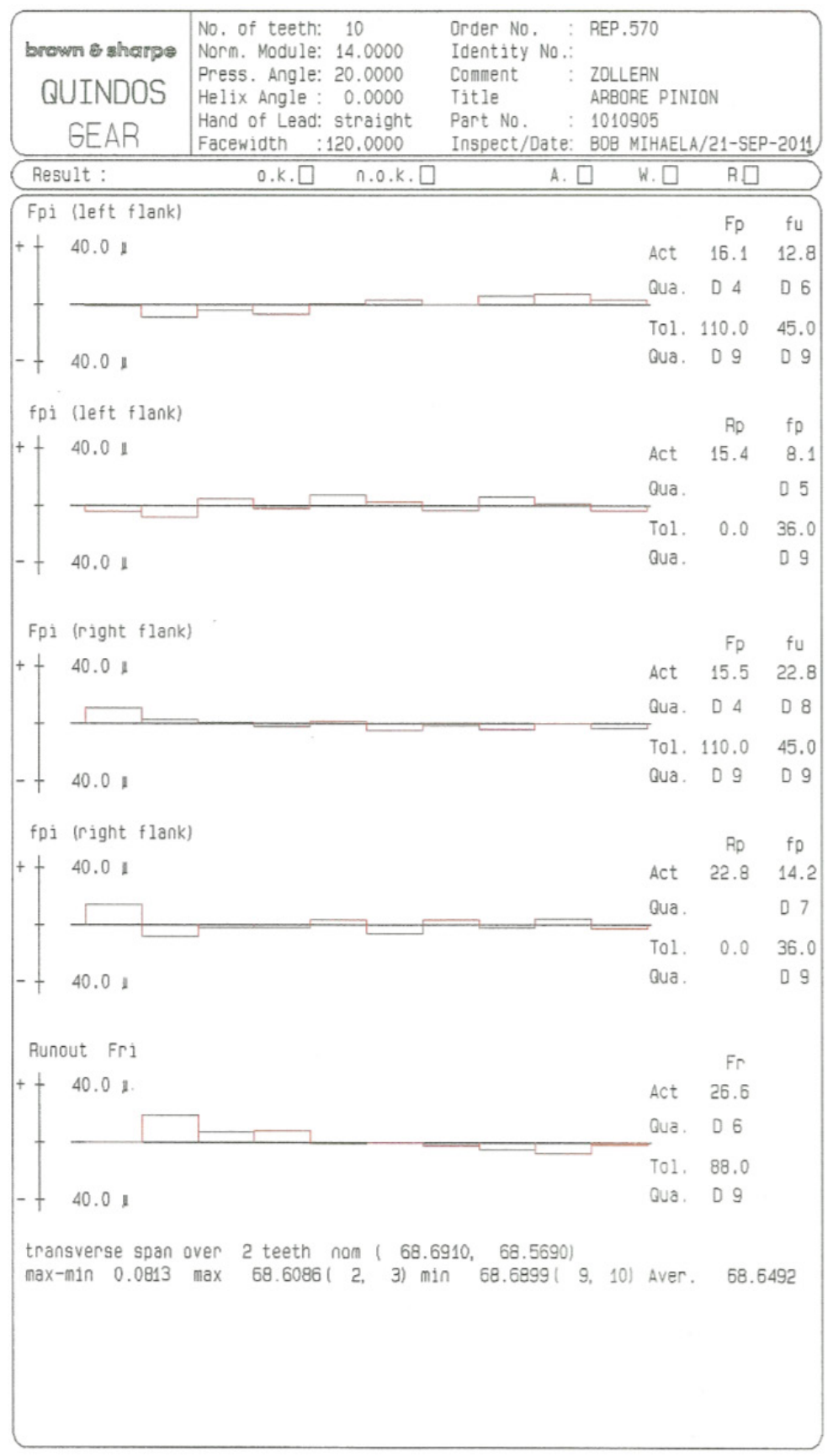

12. ábra. Osztáshibák diagramja 
A részletes ellenőrzések alapján a kifejlesztett technológiával előállított komplex profilú fogaskerekek beilleszkednek a DIN 3962 szabvány 5. pontossági osztályába, és a szélturbinákat gyártó németországi cég megfelelőknek találta.

\section{Következtetések}

A minél komplexebb konstrukciójú hajtómüvek, valamint az igényelt pontossági és müködési feltételek új technológiákat igényelnek. A CNC vezérlések nagy segítséget nyújtanak ez irányban, de ezek megfelelő programozása és beállítása megfelelő fogazáskinematikai és matematikai számításokat igényelnek. Az utolsó 4 évben csoportunk a szélturbinákban alkalmazott hajtómüvek fogaskerekei korszerü technológiájának fejlesztésével is foglalkozott. A statisztikai elörejelzések szerint 2030-ban a világ őszenergia szükséglete $\mathrm{kb}$. 50\%-kal lesz nagyobb a mostanihoz viszonyítva. A kőolajés földgáztartalékok, szintén az előrejelzések szerint, alig 2040-2070-ig tudják fedezni a szükségleteket.

A fentiek következtében a szakemberek mind jobban kell figyeljenek a megújuló energiaforrásokra, és így mind nagyobb fejlődés észlelhető a szélenergiát felhasználó turbinák fejlesztésében, gyártásában. A szélturbinák minél környezetkímélőbb müködése és élettartalma nagymértékben függ a beépített hajtómüvektől is. Ezek szerint úgy értékelhetjük, hogy a fentiekben ismertetett ez irányú kutatásaink hozzájárulhat- nak e turbinák felépítési és müködési paramétereinek javításához.

\section{Szakirodalmi hivatkozások}

[1] Bonori,G:, Optimum profile modifications of spur gears by means of genetic algorithms. Journal of Sound and Vibration Volum 313, Issue 3-5,17 June 2008. 603-616.

[2] Gyenge, Cs., Mera, M., Bâlc,N.: Research on Calculating the Parameters Value for Modification the Longitudinal Profile of the Cylindrical Gears. In: Poceedings of DAAAM 2001, 24-27 Okt. Jena. ISBN 3901-19-4,175-176..

[3] Gyenge, Cs., Bob, M, Bob, D.: Measurment of a spur gear on a BROWN\&SHARPE GHIBLI TRAX machine using QUINDOS. Anals of DAAAM for 2006 proceedings, Vienna. ISSN 1726-9679:151-152.

[4] Gyenge, Cs., Bob, M., Ros, O.: Some characteristic aspects regarding grinding of spur gears with profil modifications. In: The 20th DAAAM INTERNATIONAL SYMPOSIUM "Intelligent Manufacturing \& Automation ISSN 1726-9679. 645-646.

[5] Rafa, A., Gyenge, CS.: Some specific aspects regarding the manufacturing of renewable energy exploitation equipment. In: MicroCAD International Scientific Conference. Miskolc - Hungary 20-21 March 2010 (pag. 191-196) ISBN 978-963-661-4 0. ISBN 978-963-661-823-0. 191-196.

[6] Rafa, A., Gyenge, Cs., Pacurar, A.: Applied mathematical algorithm at the manufacturing of gears with profile modifications. Acta Tehnica Napocensis - Applied mathematics and mechanics, Volume 55, Issue 1., 249-252, 2012; ISSN- 1221-5872.

[7] http://www.insse.ro.

[8] http://www.ewea.org. 